\title{
ЛИЧНОСТЬ И ВЛАСТЬ ВО ВРЕМЕНА СТАЛИНСКИХ РЕПРЕССИЙ. ГЕРОЙ СОВЕТСКОГО СОЮЗА И.П. ЯБОРОВ: СТРАНИЦЫ БИОГРАФИИ
}

\author{
Е.П. Куртенок, \\ экскурсовод, \\ Чердынский краеведческий музей \\ им. А.С. Пушкина, Чердынь \\ kurtenok-e@mail
}

\begin{abstract}
Аннотация. На основе материалов Чердынского краеведческого музея рассматриваются события, происходившие в г. Чердыни в 1930-е гг. в отношении некоторых партийных деятелей. Статья посвящена новым фактам в биографии Героя Советского Союза Ивана Петровича Яборова. Показывается отношение местных партийных властей к человеку, который указывал на ошибки в их работе по проведению в жизнь политики партии и правительства.

Ключевые слова: комсомол; партия; руководство; обком; райком; исключение; инструктор; организация.
\end{abstract}

\section{PERSONALITY AND POWER DURING STALIN'S REPRESSIONS. HERO OF THE SOVIET UNION I.P. JABOROV: THE BIOGRAPHY}

\author{
E.P. Kurtenok, \\ guide of the \\ Cherdyn Museum of local lore. A.S. Pushkin, Cherdyn \\ kurtenok-e@mail
}

Summary. Based on the materials of Cherdyn Museum of local lore, the events that took place in the city of Cherdyn in the 1930s in relation to some party leaders are considered. The article is devoted to new facts in the biography of the Hero of the Soviet Union Yaborov Ivan Petrovich. Shows the attitude of local party authorities to the person who pointed out the mistakes in their work to implement the policy of the party and the government.

Keywords: komsomol, party; governance; regional; district; exception; instructor; organization. 
Советские политические репрессии - один из трагических этапов в истории нашей страны. Сотни тысяч поломанных судеб, перечеркнутых жизней советских людей можно записать в анналы истории Советского Союза. Трагедия для народа страны одна, а причины ее у каждого пострадавшего от репрессий свои. Людей раскулачивали, обвиняли в шпионаже и контрреволюционной деятельности, в подготовке подрывных групп, выселяли по национальному признаку, писали ложные доносы, сводили личные счеты, используя обстановку того времени. Тысячи граждан были необоснованно подвергнуты репрессиям, отправлены в исправительнотрудовые лагеря, в ссылку и на спецпоселения, приговорены к высшей мере наказания. Репрессиям подвергались ученые, рабочие, колхозники, военные, учителя, руководители учреждений и предприятий, комсомольцы и коммунисты. Клеймо «враги народа» получали целые семьи.

Не обошли репрессии и Героя Советского Союза Ивана Петровича Яборова. Его жизнь складывалась непросто. Это был человек неординарный, целеустремленный, стремившийся к самосовершенствованию, мог увлечь и повести за собой молодежь к новой социалистической жизни. Личность упорная и стойкая, Иван Петрович проявил характер в борьбе за справедливость с местной властью, представители которой, пользуясь своим преимуществом устроителей новой жизни, ломали судьбы людей в угоду личным амбициям. Они не терпели никакой критики в отношении своей деятельности и освобождались от тех, кто посмел открыто выступить против них.

И.П. Яборов родился 25 сентября 1910 г. в крестьянской семье в селе Нижняя Язьва Чердынского уезда (ныне Красновишерский район). В 1924 г. окончил школу второй ступени в своем селе. В это время отец ушел из семьи, и дальше учиться у подростка не было возможности. Он вместе со старшими братьями стал заниматься лесозаготовками и сплавом по найму. Было у них и свое крепкое хозяйство. В 1925 г. И. Яборов стал комсомольцем. Его привлекала активная деятельность комсомольцев: митинги и собрания, общественные поручения, антирелигиозные спектакли и постановки в помощь голодающим. Он много времени уделял самообразованию, старался как можно больше прочесть агитационной литературы, вникнуть в смысл политики советского госу- 
дарства. Несмотря на свой юный возраст, он проводил беседы на основе прочитанного среди взрослого населения. В апреле 1929 г. И. Яборов пошел учиться - поступил на шестимесячные курсы школы ФЗУ Вишерского лесопильного завода. Это была возможность получить хорошую рабочую специальность - брокера пиломатериала - и работать на этом же заводе. Молодой специалист участвовал в строительстве Вишерского ЦБК. Когда в селе был организован промколхоз в мае 1930 г., И.П. Яборов вместе с матерью и старшим братом вступили в колхоз, но он продолжил работать на производстве.

И.П. Яборова привлекала общественная работа, которой он отдавал все свободное время. Член общества МОПР и профсоюза, председатель ячейки общества ОСОАВИАХИМ, заведующий домом молодежи - далеко не полный перечень общественных занятий комсомольца Яборова. Кроме этого, постановка и участие в спектаклях и пьесах «на злобу дня», общественные читки и краеведческая работа, участие в субботниках и воскресниках. Его уважали не только сверстники, но и взрослые, умудренные жизнью мужики. Такая активная общественная деятельность И.П. Яборова была замечена и оценена. «В 1931 году 19 ноября по решению Чердынского РК ВЛКСМ меня переводят работать в Чердынский РК ВЛКСМ для работы кульпропагандистом», - писал в своей автобиографии Иван Петрович [1, л. 3]. В 1932 г. он вступил в члены ВКП(б). В этом же году окончил трехмесячные курсы партактива в городе Свердловске.

В ноябре 1932 г. И.П. Яборов был призван в ряды Красной армии. Он проходил службу в Дальневосточной Краснознаменной армии в 76-м Карельском стрелковом полку в городе Ворошилове (ныне Уссурийск Приморского края). Во время службы «был избран секретарем ротной ячейки, редактором газеты “Ильичевка", в 1934 г. избран парторгом учебной роты. В 1933 г. прошел партийную чистку, в заключение которой было сказано “считать проверенным”» - из автобиографии И.П. Яборова [1, л. 3]. Демобилизовался он в октябре 1935 г. и с декабря этого же года стал работать пропагандистом Чердынского РК ВКП(б).

В феврале 1936 г. молодого коммуниста назначают заведовать отделом политучебы Чердынского РК ВЛКСМ. Много времени и внимания он уделяет воспитанию молодежи: организует кружки, 
читает лекции и проводит беседы на злободневные темы, посещает все городские молодежные мероприятия, контролирует и направляет работу ячеек. У И.П. Яборова прекрасно складывалась партийная карьера, его ценили и уважали сослуживцы. Это был грамотный, добросовестный, принципиальный, прямой и честный человек.

Наступил 1937 г., в стране в очередной раз разворачивалась борьба с врагами народа. Казалось бы, пройдя чистку еще в рядах РККА, Иван Петрович мог спокойно жить и работать. Но в августе 1937 г. его исключают из членов партии и по решению бюро Чердынского РК ВЛКСМ снимают с должности завотделом политучебы Чердынского РК ВЛКСМ. Это был неожиданный удар со стороны местного партийного руководства.

Не чувствуя за собой никакой вины, 15 августа 1937 г. И.П. Яборов пишет заявление о рассмотрении его дела на бюро Свердловского обкома ВКП(б). 5 сентября пишет заявление на бюро Чердынского РК ВКП(б) о рассмотрении его дела. Дело затягивалось, ответов на его письма не было. 14 сентября он повторно написал заявление в Свердловский обком партии, а 4 октября 1937 г. - письмо в редакцию газеты «Правда» и копию отправляет уполномоченному комиссии партконтроля по Свердловской области. Еще ранее в эту же комиссию он направил заявление с просьбой разобраться в причинах молчания обкома. В письме Иван Петрович подробно написал, что явилось причиной исключения его из партии с последующим увольнением с работы. Исключили из партии и сняли с работы Яборова по инициативе секретаря Чердынского РК ВКП(б) Согрина и секретаря РК ВЛКСМ Славина. И Славина, и Согрина Иван Петрович часто критиковал за их методы работы и недальновидность. «Во время выборов РК я выступал с отводом его кандидатуры из состава РК ВКП(б), за это Согрин и его приспешники лишили меня партбилета. А сейчас он дал задание организациям не принимать меня на работу, а других источников существования у меня нет», - писал в письме в газету И.П. Яборов [1, л. 3]. «Раз ты исключен из членов ВКП(б), стало быть, ты не можешь у нас работать и конюхом. Так мне отвечал руководитель лесдревпромсоюза Якушев, напуганный Согриным. О стиле руководства Согрина я писал ранее в газету, и эти материалы из газеты отправляли на расследование Согрину же. Поэтому он хочет рассчитаться со всеми теми, кто его критиковал и критикует», - сообщал Иван Петрович в обком [1, л. 4]. 
Яборову вменили в вину и то, что в 1917-1918 гг. его отец якобы выступал против советской власти - активно помогал белым. Об этой стороне жизни отца Иван Петрович узнал только в связи с исключением его из рядов партии. Он писал в своем заявлении в райком партии: «Я не знал, что отец сотрудничал с белыми, мне тогда было 7-8 лет. Отец не рассказывал об этом, может умышленно. И не только он не говорил, но и другие тоже не рассказывали. А потом отец ушел из семьи, и мы с ним не общались с 1925 по 1936 г. Он стал врагом всей нашей семье. А меня из партии исключили из-за действий отца. Я с ним не воспитывался и не жил, меня воспитала партия - комсомол» [2, л. 3].

25 августа 1937 г. Яборов побывал в селе Нижняя Язьва, взял справку в сельсовете о социально-имущественном положении семьи, поговорил со стариками об отце. Те ничего не смогли рассказать о помощи его отца белым, так как не помнят, чтобы он сотрудничал с ними. Два месяца Иван Петрович пытался устроиться на работу, но его нигде не принимали. Семья с двумя маленькими детьми осталась без средств существования. В это время умирает его маленькая дочь, болеет жена Мария Дмитриевна. Косые взгляды соседей и знакомых, нежелание бывших сослуживцев общаться с ним, несправедливость и безденежье усугубляли состояние Ивана Петровича и жизнь семьи. Наконец, в октябре 1937 г. его приняли в детский дом «завтранспортом подсобного хозяйства», в ноябре перевели на должность экспедитора детского дома. Все это время Иван Петрович ждал вызова или каких-то действий со стороны обкома партии. И Свердловский обком разобрался в деле Ивана Петровича. После нескольких месяцев терзаний и ожидания его восстановили в партии. Произошли изменения и в партийной работе. «Назначен Чердынским РК ВКП(б) инструктором РК ВКП(б). Основание - Решение бюро Чердынского РК ВКП(б)», - запись в трудовом списке Ивана Петровича от 8 января 1938 г. [3, л. 4]. Позднее он был избран вторым секретарем райкома ВКП(б) и в этой должности проработал до призыва на фронт.

Иван Петрович ушел на войну в ноябре 1941 г. В начале 1942 г. окончил курсы политработников. Служил заместителем командира по политической части моторизованного батальона автоматчиков 3-й Гвардейской танковой бригады. Гвардии майор Иван Яборов погиб во время уличных боев в городе Вильнюсе 
9 июля 1944 г. В марте 1945 г. ему было посмертно присвоено звание Героя Советского Союза. Так геройски закончился его земной путь.

Пример И.П. Яборова показывает, как может измениться жизнь человека и его семьи от оговора и умышленной травли человека. Не очень сложно представить, как сложилась бы дальнейшая судьба Ивана Петровича, если бы обком партии не разобрался в этой ситуации и не поддержал его. Возможно, представители местной власти, его противники и дальше продолжили борьбу с ним, нашли бы причину для ареста, чтобы избавиться от неудобного человека. Но жизнь распорядилась иначе. Иван Петрович Яборов совершил подвиг, защищая свою Родину от врагов, и остался навечно в истории страны и Чердыни, одна из улиц города названа его именем. А его противников сегодня не помнит никто.

\section{Список литературы и источников}

1. Чердынский краеведческий музей (ЧКМ) н/в № 1702/34. Автобиография Яборова И.П.

2. ЧКМ н/в № 1702/43. Заявление на бюро РК ВКП(б).

3. ЧКМ н/в № 1702/38. Трудовой список Яборова И.П. 